\title{
Induction of osteogenic markers in differentially treated cultures of embryonic stem cells
}

\author{
Jörg Handschel*1, Karin Berr'1, Rita A Depprich ${ }^{1}$, Norbert R Kübler ${ }^{1}$, \\ Christian Naujoks ${ }^{1}$, Hans-Peter Wiesmann ${ }^{2}$, Michelle A Ommerborn ${ }^{3}$ and \\ Ulrich Meyer ${ }^{1}$
}

\begin{abstract}
Address: ${ }^{1}$ Department for Cranio- and Maxillofacial Surgery, Heinrich-Heine-University Düsseldorf, Moorenstr. 5, 40225 Düsseldorf, Germany, ${ }^{2}$ Department for Cranio- and Maxillofacial Surgery, Westfälische-Wilhelms-Universität Münster, Waldeyerstr. 30, 48149 Münster, Germany and ${ }^{3}$ Department for Operative and Preventive Dentistry and Endodontics, Heinrich-Heine-University Düsseldorf, Moorenstr. 5, 40225 Düsseldorf, Germany

Email: Jörg Handschel* - handschel@t-online.de; Karin Berr - handschel@med.uni-duesseldorf.de; Rita A Depprich - depprich@med.uniduesseldorf.de; Norbert R Kübler - kubler@med.uni-duesseldorf.de; Christian Naujoks - christian.naujoks@med.uni-duesseldorf.de; HansPeter Wiesmann - HansPeter.Wiesmann@ukmuenster.de; Michelle A Ommerborn - ommerborn@med.uni-duesseldorf.de;

Ulrich Meyer - ulrich.meyer@med.uni-duesseldorf.de

* Corresponding author
\end{abstract}

Published: 10 June 2008

Head \& Face Medicine 2008, 4:10 doi:10.1186/1746-160X-4-10

This article is available from: http://www.head-face-med.com/content/4/1/10

(C) 2008 Handschel et al; licensee BioMed Central Ltd.

This is an Open Access article distributed under the terms of the Creative Commons Attribution License (http://creativecommons.org/licenses/by/2.0), which permits unrestricted use, distribution, and reproduction in any medium, provided the original work is properly cited.
Received: 30 July 2007

Accepted: 10 June 2008

\begin{abstract}
Background: Facial trauma or tumor surgery in the head and face area often lead to massive destruction of the facial skeleton. Cell-based bone reconstruction therapies promise to offer new therapeutic opportunities for the repair of bone damaged by disease or injury. Currently, embryonic stem cells (ESCs) are discussed to be a potential cell source for bone tissue engineering. The purpose of this study was to investigate various supplements in culture media with respect to the induction of osteogenic differentiation.
\end{abstract}

Methods: Murine ESCs were cultured in the presence of LIF (leukemia inhibitory factor), DAG (dexamethasone, ascorbic acid and $\beta$-glycerophosphate) or bone morphogenetic protein-2 (BMP2). Microscopical analyses were performed using von Kossa staining, and expression of osteogenic marker genes was determined by real time PCR.

Results: ESCs cultured with DAG showed by far the largest deposition of calcium phosphatecontaining minerals. Starting at day 9 of culture, a strong increase in collagen I mRNA expression was detected in the DAG-treated cells. In BMP-2-treated ESCs the collagen I mRNA induction was less increased. Expression of osteocalcin, a highly specific marker for osteogentic differentiation, showed a double-peaked curve in DAG-treated cells. ESCs cultured in the presence of DAG showed a strong increase in osteocalcin mRNA at day 9 followed by a second peak starting at day 17.

Conclusion: Supplementation of ESC cell cultures with DAG is effective in inducing osteogenic differentiation and appears to be more potent than stimulation with BMP-2 alone. Thus, DAG treatment can be recommended for generating ESC populations with osteogenic differentiation that are intended for use in bone tissue engineering. 


\section{Background}

Facial trauma or tumor surgery in the head and face area often lead to massive destruction of the facial skeleton [1]. The reconstruction of damaged or lost bone is a clinical challenge in modern reconstructive surgery. The repair of bone defects still poses a significant problem for many clinicians. In the early decades of bone reconstruction surgeons used artificial tissue substitutes containing metals, ceramics, and polymers to maintain skeletal function [2]. These artificial materials have facilitated surgeons to restore the form and - to some extent - the function of defective bones. Nevertheless, these artificial materials have specific disadvantages, and thus encouraged surgeons to develop alternative approaches including cellbased devices. Transplantation of autografts is a frequently used treatment strategy in routine clinical practice and has gained the "gold standard" in bone reconstructive surgery, despite donor site morbidity and donor shortage [3].

Modern cell-based bone reconstruction techniques may offer new therapeutic opportunities for the repair of bone damaged by disease or injury. Generally, the combination of scaffolds, bioactive factors, and living cells provides a surgically implantable product for use in tissue regeneration and functional restoration $[4,5]$. Numerous attempts were undertaken with various success to restore bone defects by various biomaterials alone [6-10] or in combination with bioactive cytokines such as bone morphogenetic protein (BMP)-7, BMP-2 or BMP-2-mutants [11,12]. Cell-based strategies in bone tissue engineering use different cell sources including autologous cells as well as allogenic and xenogenic cells [13-16]. There are some reports that use totipotential embryonic stem cells in tissue engineering of bone $[17,18]$.

Embryonic stem cells (ESCs) are routinely derived from the inner cell mass of blastocysts and represent pluripotential embryonic precursor cells that give rise to all cell types in the developing organism. ESCs have historically been maintained in co-culture with mitotically inactive fibroblasts [19-21]. This co-culture system is unnecessary if the medium is supplemented with leukemia inhibitory factor (LIF) [22,23]. In the absence of LIF embryonic stem cells will differentiate into a morphologically mixed cell population expressing features of endoderm and mesoderm lineages [24]. By definition ESCs have the potential to differentiate into osteogenic cells under selective culture conditions. Specifically, it has been shown by various investigators that ESCs can differentiate into osteogenic cells under selective culture conditions $[17,18,25]$. However, it is unclear which medium is most suitable to initiate osteogenic differentiation. BMP-2 and a mixture of dexamethasone, ascorbic acid and $\beta$-glycerophosphate (DAG) are good candidates $[19,25]$. Thus, we examined the time-dependent expression of the osteoblastic markers osteopontin [26], collagen I [27], alkaline phosphatase [28], and osteocalcin [29] in ESC cells.

\section{Methods}

\section{Culture of ESCs with biomaterials}

Feeder-independent murine ESCs were derived from the inner cell mass of blastocysts extracted from C57BL/6 mice. The ESCs were kindly provided by K. Pfeffer (Institute for Microbiology, Heinrich-Heine-University, Germany). The cells were tested to be positive for the stem cell marker Pouf1 (alias Oct4) and Foxd3 [30] (data not shown). A total number of $1.5 \times 10^{6}$ cells per petri dish (10 cm in diameter) were cultured in Dulbecco's Eagle medium (DMEM). The medium was supplemented with $5 \mathrm{mM}$ glutamine, 100 units $/ \mathrm{ml}$ penicillin, $100 \mu \mathrm{g} / \mathrm{ml}$ streptomycin, $50 \mu \mathrm{M}$ 2-mercaptoethanol and 15\% fetal calf serum (FCS). The ESCs were divided into four groups and cultured for 25 days as follows: group I; control, supplemented with LIF to prevent differentiation, group II; no additional supplement, group III; supplemented with BMP-2 (10 ng/ml), and group IV; supplemented with DAG (dexamethasone $(0.1 \mu \mathrm{M})$, ascorbic acid $(50 \mu \mathrm{M})$ and $\beta$-glycerophosphate $(10 \mathrm{mM})$.

\section{Microscopical analyses}

To detect mineralization in the differently treated cell cultures, the cells were washed two times with PBS (phosphate-buffered saline) before fixation with $3 \%$ glutardialdehyde in PBS for 30 minutes. The cells were washed with distilled water and incubated in 5\% silver nitrate (Sigma Aldrich) for 1 hour. The cells were washed again with distilled water. A solution of $5 \%$ sodium carbonate and $10 \%$ formaldehyde was added for 2 minutes before the cells were washed again and fixed with $1 \%$ sodium thiosulfate. Calcium-phosphate deposits stained black $[31,32]$.

\section{Quantitative real time PCR}

Quantitative real time PCR was employed to assess the influence of the biomaterials on gene expression. Total RNA was isolated from specimens using the RNeasy Mini Kit (Qiagen, Hilden, Germany) according to the manufacturer's instructions. For cDNA synthesis $800 \mathrm{ng}$ total RNA was used as a template for Superscript II (Invitrogen, Paisley, UK) and OligodT-Primers (Peqlab, Erlangen, Germany) in a total volume of $20 \mu \mathrm{l}$. Amplification was performed with $1 \mu \mathrm{l}$ of cDNA and the following specific primer pairs (MWG-Biotech AG, Ebersberg, Germany): CD34; 5'-CACAGAACTTCCCAGCAAACTC-3' and 5'CATGTTGTCTTGCTGAATGGCC-3', osteopontin; 5'CCCGGTGAAAGTGACTGATT-3' and 5'-TTCTTCAGAGGACACAGCATTC-3', osteocalcin; 5'-GCCCTGAGTCTGACAAAGGTA-3' and 5'-GGTGATGGCCAAGACTAAGG3', collagen type I; 5'-AAGGGGTCTTCCTGGTGAAT-3' 
and 5'-GGGGTACCACGTTCTCCTC-3', alkaline phosphatases; 5'-AAGGCTTCTTCTTGCTGGTG-3' and 5'GCCTTACCCTCATGATGTCC-3', and GAPDH; 5'-CAATGAATACGGCTACAGCAAC-3' and 5'-AGGGAGATGCTCAGTGTTGG-3'. For quantitative real time PCR the iCycler Thermal Cycler Base (Bio-Rad Laboratories GmbH, München, Germany) and qPCR MasterMix, No Rox, \#RT-QP2X-03NR (Eurogentec, Köln, Germany) was used. The increase in reaction products during PCR was monitored by measuring the increase in fluorescence intensity caused by the binding of SYBR green to doublestranded DNA that accumulated during PCR cycles. Reaction mixtures were set up as suggested by the manufacturer. Threshold cycle values of target genes were standardized against GAPDH expression and normalized to the expression in the control culture (group I). All real time experiments in this study have been performed with regard to the publication of Pfaffl [33]. We have applied the mathematical model given there to eliminate deviations due to sample preparation. In order to apply this model it is necessary to choose a reference gene (e.g. GAPDH) for calculating relative expression levels. The quantitative real time PCR was performed in samples obtained at day 5, 9, 11, 13, 15, 17, 19, 21, 23, and 25 of culture, respectively. Following PCR agarose-gel electrophoresis was performed using $\beta$-actin as a reference.
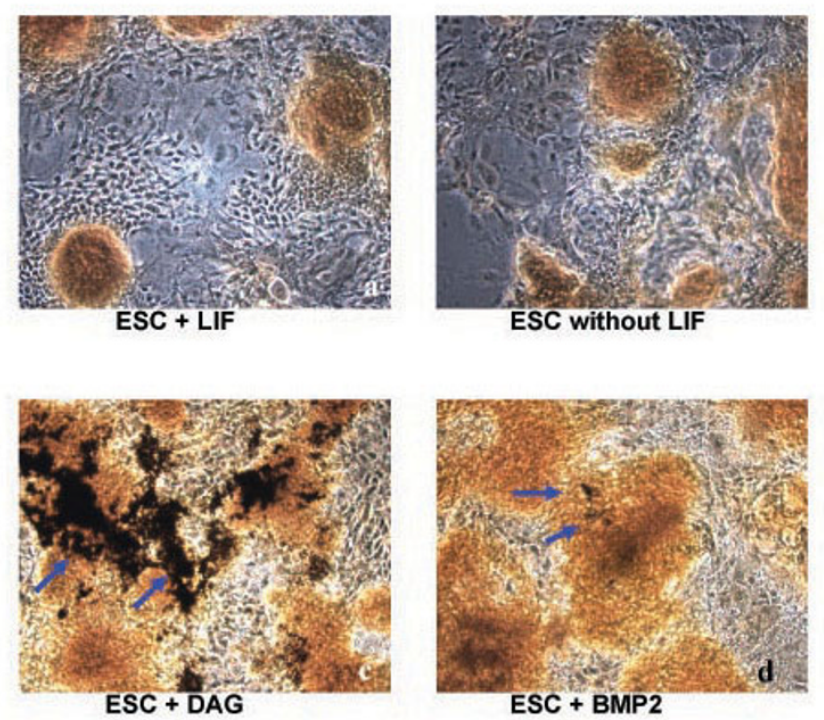

\section{Figure I}

Mineral deposition at day 14 in differently treated embryonic stem cells (ESCs). Cells were exposed to (a) LIF (leukemia inhibitory factor), (b) without LIF, (c) DAG (dexamethasone, ascorbic acid and $\beta$-glycerophosphate) or (d) BMP-2. Shown are von Kossa stainings with arrows pointing to the deposition of calcium phosphate-containing minerals that stained in black.

\section{Results}

In ESC cultures supplemented with DAG we found the largest deposition of calcium phosphate-containing minerals, as judged by von Kossa staining (Fig. 1). ESCs cultured in the presence of BMP-2 exhibited less mineralization, and there were no signs of mineral deposition in unstimulated control cells or cells stimulated with LIF.

In order to assess the differentiation of ESCs cultured under different conditions, we used the hematopoetic stem cell marker CD34. Only in ESC cultures without any additional stimulus (ESCs without LIF) the expected amplicon appeared in agarose-gel electrophoresis. ESCs which were differentiated with BMP-2 or DAG have downregulated this marker (Fig. 2).

Next the kinetics of gene expression in ESCs during differentiation and matrix formation were evaluated. The values were plotted as a multiple of the expression in the control group (ESCs with LIF). Expression of osteopontin was reduced in ESC treated with LIF as compared to all other samples (without LIF, with BMP-2 or with DAG). The low level of osteopontin mRNA synthesis persisted in the presence of DAG, and in BMP-2-treated cells showed a steep increase after 2.5 weeks of culture. ESCs without LIF showed similar expression rates as the DAG group (Fig. 3).

Starting at day 9 of culture, a strong increase in collagen I expression was recorded in the DAG culture, which was

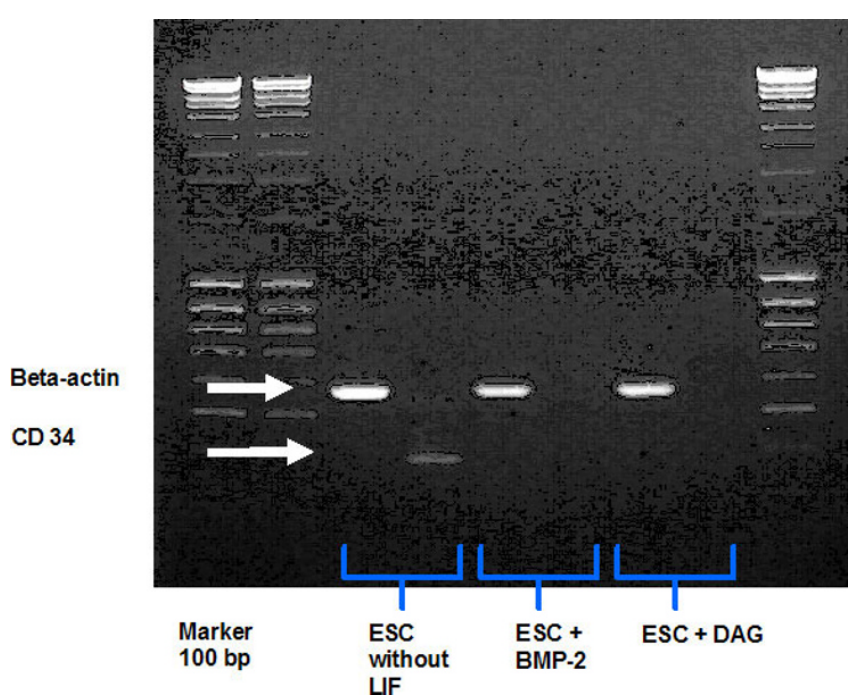

Figure 2

Results from qualitative PCR showing amplification of the hematopoetic stem cell marker CD34 in ESC cells treated (a) without LIF, (b) with BMP-2, or (c)

DAG. Beta-actin was used as control. 


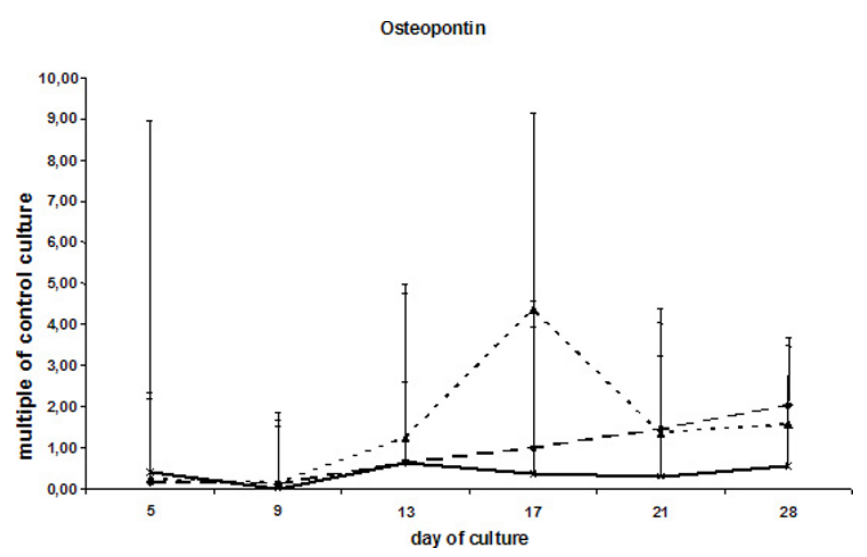

Figure 3

mRNA levels for osteopontin in ESCs cultured with DAG

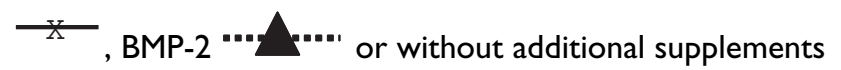

(ESC without LIF) $-\neg-$. Values are calculated as multiples of the transcription level of the control culture (ESC with LIF). Shown as mean values and standard deviations normalized to the expression of GAPDH.

paralleled to a lesser extent by the collagen expression in the BMP-2-treated cells. After three weeks of culture the expression level of collagen I mRNA was similar in all groups of the differentially treated cells (Fig. 4). Only the DAG culture showed a second but smaller increase at day 23.

The transcription of mRNA coding for alkaline phosphatase was slightly increased in cells stimulated with BMP-2. ESCs exposed to DAG did not significantly differ from the control culture (Fig. 5). Expression of osteocalcin, which is regarded as a highly specific marker for osteoblasts, demonstrated showed a double-peaked curve in the DAG-treated cells. ESCs cultured in DAG-supplemented medium showed a prominent peak after 9 days and a second peak beginning at day 17 . The first increase was also seen in ESCs cultured in the presence of BMP-2 or the absence of LIF. Interestingly, in all the differentially treated cells a second peak of osteocalcin transcription was observed 7 days later (Fig. 6). All three ESC cultures showed similar expression pattern of the hematopoetic stem cell marker CD34 (Fig. 7).

\section{Discussion}

Currently, there are many efforts to establish cell-based strategies in bone tissue engineering. ESCs are one of many different cell populations, which are being tested for their feasibility for these treatment options. The purpose of this investigation was to determine which supplements in culture medium are most suitable to initiate

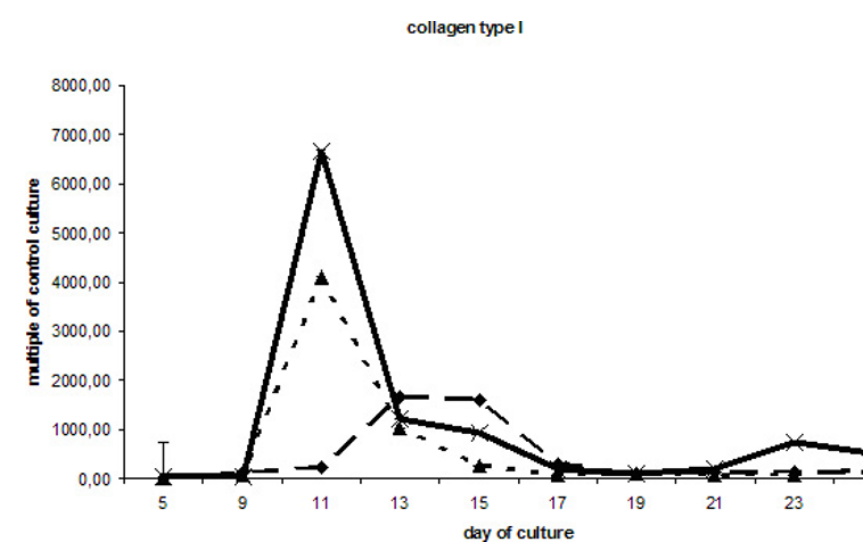

Figure 4

Expression of collagen I transcripts in differentially treated ESCs cultures: DAG ${ }^{x}$, BMP-2 -...' and without additional supplements (ESC without LIF) $-\downarrow-$. Values are calculated as multiples of the transcription level of the control culture (ESC with LIF) and shown as mean values and standard deviations after normalisation against GAPDH.

osteogenic differentiation in ESC cultures. In addition, we investigated the kinetics of gene expression during in vitro differentiation.

The results of our microscopical analysis revealed that ESCs cultured in the presence of DAG show by far the highest extent of mineralisation as determined by the occurrence of calcium-phosphate-containing crystals. With respect to extracellular matrix maturation and mineral deposition as crucial steps in the osteogenic cascade [34], DAG seems to be the most promising supplement for inducing osteogenic differentiation in ESCs. In accordance with our microscopical results, a strong increase of collagen I expression was observed at day 11 in the DAGtreated cells. Stimulation with BMP-2 also increased collagen synthesis. Expression of osteocalcin mRNA followed a different pattern and appeared as a double-peaked curve, when ESCs were supplemented with osteogenic agents (DAG or BMP-2). However, the peak induction of osteocalcin mRNA in the BMP-2-treated cells was lower and delayed as compared to DAG-exposed cells. Taken together, these results support the use of DAG as a potent agent for inducing in vitro differentiation of ESCs into osteoblast-like cells.

There are only few reports addressing osteogenic differentiation of ESCs published in the literature so far $[18,25,34,35]$. In agreement with these results we describe here that mineralisation is microscopically evident as early as two weeks of culture. Buttery and co-workers also used DAG as a culture supplement and found that miner- 


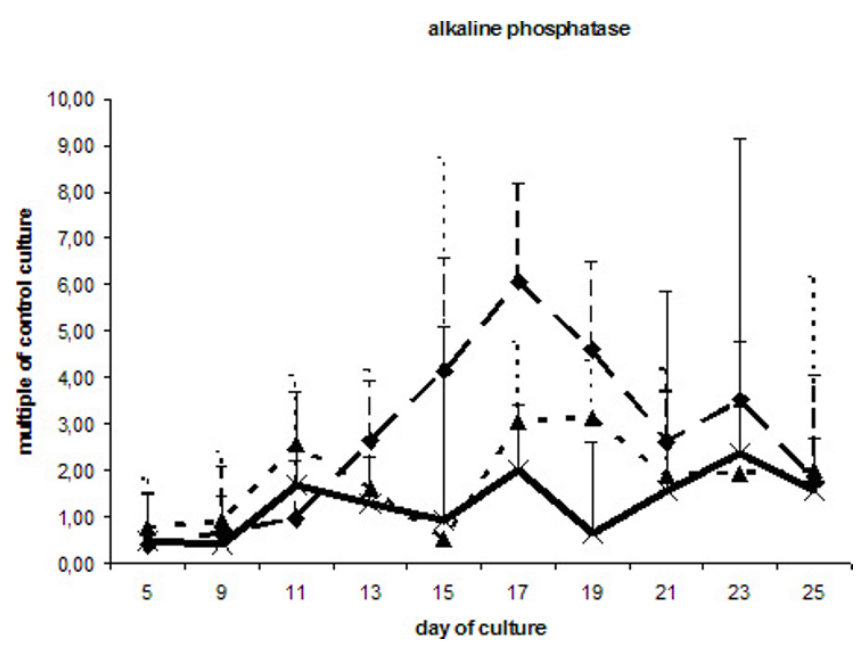

Figure 5

mRNA levels of alkaline phosphatase in ESCs cultured with DAG $\stackrel{x}{\triangle}$, BMP-2 "...' and without additional supplements (ESC without LIF) $-\prec-$. Data are presented as in Fig. 3.

alisation was detectable when dexamethasone was added only at day 14 or later [35]. By following this protocol the differentiation process was delayed as compared to the findings in our ESC cultures. While Buttery used only microscopical methods for studying osteogenic differentiation, zur Nieden and colleagues performed also gene expression analyses for osteogenic markers [34]. With respect to the time-course of gene expression with an early

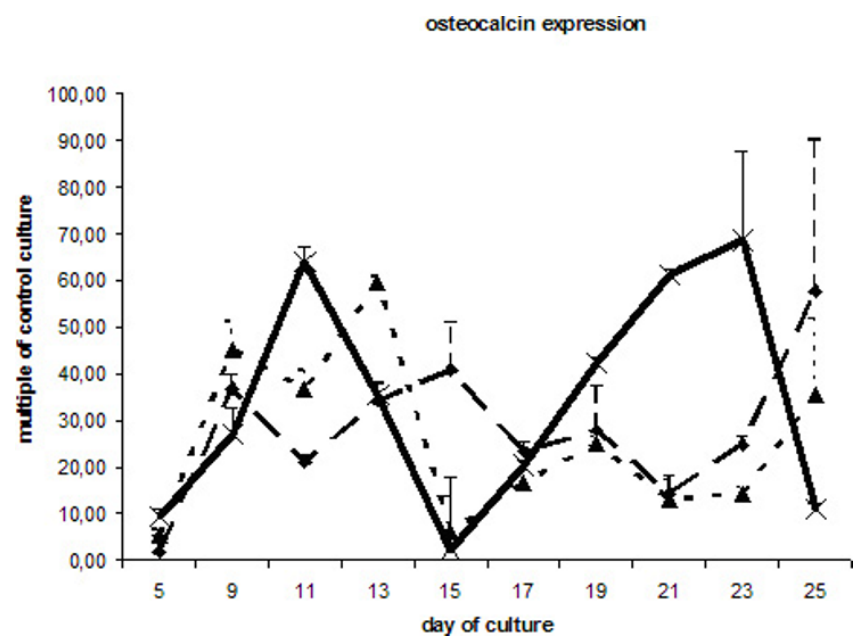

Figure 6

mRNA levels of osteocalcin in ESCs cultured with DAG

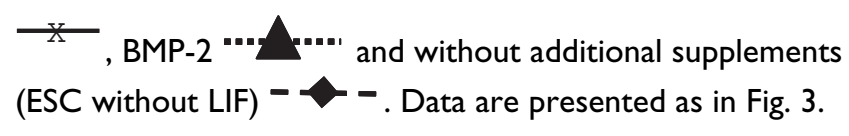

increase of collagen I and a later increase of osteocalcin transcripts, their data are comparable to our findings as shown above. Unlike to the findings of zur Nieden and colleagues, an early peak of osteocalcin expression and a minor increase of osteopontin were found in the presented study. The differences could be explained by different concentrations of supplements used for cell differentiation. Zur Nieden et al. used 1,25-OH vitamin $\mathrm{D}_{3}$ instead of dexamethasone. According to Zhang et al. vitamin $\mathrm{D}_{3}$ increases osteopontin expression in osteoblasts and inhibits expression of osteocalcin [36]. Chaudhry and co-workers replaced dexamethasone with retinoid acid, which was found to be an inductor of mineralization in three-dimensional scaffolds [25]. Notably, alkaline phosphatase was constitutively expressed at high levels in undifferentiated cells [37]. In this experimental setting the mineralisation process was delayed and was detectable only after day 21. Treatment with DAG appeared to be equal or even superior to BMP-2 stimulation regarding the induction of osteogenic differentiation in ESCs. Other authors have used BMP-2 in combination with osteogenic supplements for this purpose $[18,38]$.

An advantage of using ESCs instead of tissue-derived progenitor cells is that ESCs are immortal and could potentially provide an unlimited supply of differentiated osteoblast and osteoprogenitor cells for transplantation. In contrast to embryonic cells, the proliferative, selfrenewal and differentiation capacity of cells derived from adult tissues generally decreases with age $[39,40]$. One major challenge pointing to the use of ESCs lies in overcoming immunological rejection from the transplant recipient. Interestingly, Burt and colleagues performed

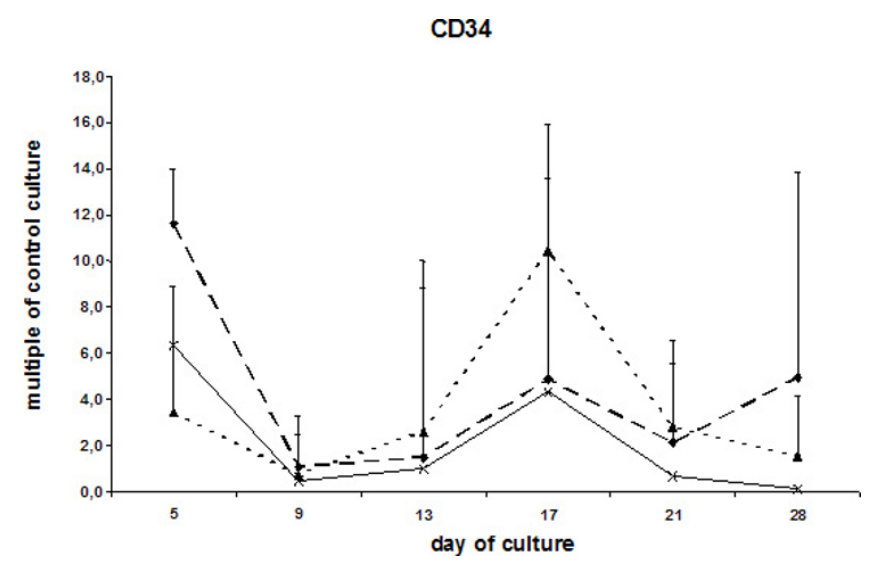

Figure 7

mRNA levels of CD34 expression in ESCs cultured with

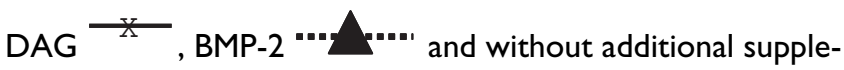
ments (ESC without LIF) $-\neg$. Data are presented as in Fig. 3. 
ESC transplantation in major histocompatibility complex (MHC)-mismatched mice without clinical or histological evidence of graft-versus-host disease (GVHD) [21]. In addition, recent data indicate that ESCs may allow for a low-risk induction of tolerance not requiring any immunosuppression [41].

In conclusion, ESCs differentiate into osteoblast-like cells in vitro when stimulated with DAG and showed a timedependent induction of osteogenic markers. Thus, stimulation with these agents is suitable to generate a promising cell population used for bone tissue engineering.

\section{Competing interests}

The authors declare that they have no competing interests.

\section{Authors' contributions}

$\mathrm{JH}$ conceived the study, calculated the statistics and drafted the manuscript, KB carried out the cell culture and the gene expression analysis, HW helped to perform and evaluate the histological investigations, $\mathrm{RD}, \mathrm{CN}, \mathrm{MO}, \mathrm{NK}$ and UM participated in its design and coordination and helped to draft the manuscript. All authors read and approved the final manuscript.

\section{Acknowledgements}

We are very grateful to Prof. Dr. K. Pfeffer, Institut für Mikrobiologie an der Heinrich-Heine-Universität Düsseldorf, who provided the murine ESCs.

\section{References}

I. Malara P, Malara B, Drugacz J: Characteristics of maxillofacial injuries resulting from road traffic accidents - a 5 year review of the case records from Department of Maxillofacial Surgery in Katowice, Poland. Head Face Med 2006, 2:27.

2. Binderman I, Fin N: Bone substitutesorganic, inorganic, and polymeric: Cell material interactions. In CRC Handbook of Bioactive Ceramics Edited by: Yamamuro T, Hench L, Wilson J. Boca Raton, Florida , CRC Press; 1990:45-5I.

3. Damien CJ, Parsons JR: Bone graft and bone graft substitutes: a review of current technology and applications. J Appl Biomater | 99|, 2(3): 187-208.

4. Tuan RS, Boland G, Tuli R: Adult mesenchymal stem cells and cell-based tissue engineering. Arthritis Res Ther 2003, 5(I):32-45.

5. Vacanti CA, Vacanti JP: Bone and cartilage reconstruction with tissue engineering approaches. Otolaryngol Clin North Am 1994, 27(I):263-276.

6. Cohen SR, Holmes RE, Meltzer HS, Levy ML, Beckett MZ: Craniofacial reconstruction with a fast resorbing polymer: a 6- to I 2month clinical follow-up review. Neurosurg Focus 2004, 16(3): EI2.

7. Handschel J, Wiesmann HP, Stratmann U, Kleinheinz J, Meyer U, Joos $\mathrm{U}:$ TCP is hardly resorbed and not osteoconductive in a nonloading calvarial model. Biomaterials 2002, 23(7): 1689-1695.

8. Holmes RE, Cohen SR, Cornwall GB, Thomas KA, Kleinhenz KK, Beckett MZ: MacroPore resorbable devices in craniofacial surgery. Clin Plast Surg 2004, 3 I (3):393-406, v.

9. Thaller SR, Hoyt J, Borjeson K, Dart A, Tesluk H: Reconstruction of calvarial defects with anorganic bovine bone mineral (BioOss) in a rabbit model. J Craniofac Surg 1993, 4(2):79-84.

10. Velich N, Nemeth Z, Hrabak K, Suba Z, Szabo G: Repair of bony defect with combination biomaterials. J Craniofac Surg 2004, I5(I):II-I5.

II. Kubler NR, Wurzler KK, Reuther JF, Sieber E, Kirchner T, Sebald W: [Effect of different factors on the bone forming properties of recombinant BMPs]. Mund Kiefer Gesichtschir 2000, 4 Suppl 2:S465-9.

12. Terheyden H, Knak C, Jepsen S, Palmie S, Rueger DR: Mandibular reconstruction with a prefabricated vascularized bone graft using recombinant human osteogenic protein-I: an experimental study in miniature pigs. Part I: Prefabrication. Int J Oral Maxillofac Surg 200I, 30(5):373-379.

13. Meyer U, Wiesmann HP: Tissue engineering: a challenge of today's medicine. Head Face Med 2005, I:2.

14. Puricelli E, Ulbrich LM, Ponzoni D, Filho JJ: Histological analysis of the effects of a static magnetic field on bone healing process in rat femurs. Head Face Med 2006, 2:43.

15. Handschel J, Wiesmann HP, Depprich R, Kubler NR, Meyer U: Cellbased bone reconstruction therapies--cell sources. Int J Oral Maxillofac Implants 2006, 2 I (6):890-898.

16. Yamaguchi M, Hirayama F, Murahashi $\mathrm{H}$, Azuma $\mathrm{H}$, Sato N, Miyazaki H, Fukazawa K, Sawada K, Koike T, Kuwabara M, Ikeda H, Ikebuchi $\mathrm{K}$ : Ex vivo expansion of human UC blood primitive hematopoietic progenitors and transplantable stem cells using human primary $B M$ stromal cells and human $A B$ serum. Cytotherapy 2002, 4(2): 109-1 I8.

17. Heng BC, Cao T, Stanton LW, Robson P, Olsen B: Strategies for directing the differentiation of stem cells into the osteogenic lineage in vitro. J Bone Miner Res 2004, 19(9): I379-1394.

18. zur Nieden NI, Kempka G, Rancourt DE, Ahr HJ: Induction of chondro-, osteo- and adipogenesis in embryonic stem cells by bone morphogenetic protein-2: effect of cofactors on differentiating lineages. BMC Dev Biol 2005, 5(I): I.

19. Bielby RC, Boccaccini AR, Polak JM, Buttery LD: In vitro differentiation and in vivo mineralization of osteogenic cells derived from human embryonic stem cells. Tissue Eng 2004, 10(910): $1518-1525$.

20. Evans MJ, Kaufman MH: Establishment in culture of pluripotential cells from mouse embryos. Nature I98I, 292(58 I 9): I54- 156.

21. Burt RK, Verda L, Kim DA, Oyama Y, Luo K, Link C: Embryonic stem cells as an alternate marrow donor source: engraftment without graft-versus-host disease. J Exp Med 2004, 199(7):895-904.

22. Chambers I: The molecular basis of pluripotency in mouse embryonic stem cells. Cloning Stem Cells 2004, 6(4):386-39I.

23. Smith AG, Heath JK, Donaldson DD, Wong GG, Moreau J, Stahl M, Rogers D: Inhibition of pluripotential embryonic stem cell differentiation by purified polypeptides. Nature 1988, 336(6200):688-690.

24. Niwa H, Miyazaki J, Smith AG: Quantitative expression of Oct-3/ 4 defines differentiation, dedifferentiation or self-renewal of ES cells. Nat Genet 2000, 24(4):372-376.

25. Chaudhry GR, Yao D, Smith A, Hussain A: Osteogenic Cells Derived From Embryonic Stem Cells Produced Bone Nodules in Three-Dimensional Scaffolds. J Biomed Biotechnol 2004, 2004(4):203-210.

26. McKee MD, Nanci A: Osteopontin: an interfacial extracellular matrix protein in mineralized tissues. Connect Tissue Res 1996, 35(I-4):197-205.

27. Bilezikian JP, Raisz LG, Rodan GA: Principles of Bone Biology. San Diego , Academic Press, Inc.; 1996.

28. Zernik J, Twarog K, Upholt WB: Regulation of alkaline phosphatase and alpha 2(I) procollagen synthesis during early intramembranous bone formation in the rat mandible. Differentiation 1990, 44(3):207-215.

29. Aubin JE, Liu F: The osteoblast lineage. In Principles of Bone Biology Edited by: Bilezikian JP, Raisz LG, Rodan GA. San Diego , Academic Press; 1996:51-67.

30. Baharvand H, Ashtiani SK, Taee A, Massumi M, Valojerdi MR, Yazdi PE, Moradi SZ, Farrokhi A: Generation of new human embryonic stem cell lines with diploid and triploid karyotypes. Dev Growth Differ 2006, 48(2): I 17-128.

31. Koch TG, Heerkens T, Thomsen PD, Betts DH: Isolation of mesenchymal stem cells from equine umbilical cord blood. $B M C$ Biotechnol 2007, 7:26.

32. Mizobuchi M, Ogata H, Hatamura I, Koiwa F, Saji F, Shiizaki K, Negi S, Kinugasa E, Ooshima A, Koshikawa S, Akizawa T: Up-regulation of Cbfal and Pit-I in calcified artery of uraemic rats with severe hyperphosphataemia and secondary hyperparathyroidism. Nephrol Dial Transplant 2006, 2 1(4):911-916. 
33. Pfaff MW: A new mathematical model for relative quantification in real-time RT-PCR. Nucleic Acids Res 200I, 29(9):e45.

34. zur Nieden NI, Kempka G, Ahr HJ: In vitro differentiation of embryonic stem cells into mineralized osteoblasts. Differentiation 2003, 7 I (I): 18-27.

35. Buttery LD, Bourne S, Xynos JD, Wood H, Hughes FJ, Hughes SP, Episkopou V, Polak JM: Differentiation of osteoblasts and in vitro bone formation from murine embryonic stem cells. Tissue Eng 200I, 7(I):89-99.

36. Zhang R, Ducy P, Karsenty G: I,25-dihydroxyvitamin D3 inhibits Osteocalcin expression in mouse through an indirect mechanism. J Biol Chem 1997, 272(I): I I0-II6.

37. Phillips BW, Belmonte N, Vernochet C, Ailhaud G, Dani C: Compactin enhances osteogenesis in murine embryonic stem cells. Biochem Biophys Res Commun 200I, 284(2):478-484.

38. Yamashita A, Takada T, Narita J, Yamamoto G, Torii R: Osteoblastic differentiation of monkey embryonic stem cells in vitro. Cloning Stem Cells 2005, 7(4):232-237.

39. D'lppolito G, Schiller PC, Ricordi C, Roos BA, Howard GA: Agerelated osteogenic potential of mesenchymal stromal stem cells from human vertebral bone marrow. J Bone Miner Res 1999, I4(7): III5-II 22.

40. Quarto R, Thomas D, Liang CT: Bone progenitor cell deficits and the age-associated decline in bone repair capacity. Calcif Tissue Int 1995, 56(2): I 23-129.

41. Zavazava N: Embryonic stem cells and potency to induce transplantation tolerance. Expert Opin Biol Ther 2003, 3(I):5-13.

Publish with Bio Med Central and every scientist can read your work free of charge

"BioMed Central will be the most significant development for disseminating the results of biomedical research in our lifetime. "

Sir Paul Nurse, Cancer Research UK

Your research papers will be:

- available free of charge to the entire biomedical community

- peer reviewed and published immediately upon acceptance

- cited in PubMed and archived on PubMed Central

- yours - you keep the copyright

Submit your manuscript here:

http://www.biomedcentral.com/info/publishing_adv.asp
BioMedcentral 